\title{
Costs and healthcare utilisation of patients with chronic kidney disease in Spain
}

\author{
Carlos Escobar ${ }^{1 *}$, Beatriz Palacios², Unai Aranda², Margarita Capel², Antoni Sicras ${ }^{3}$, Aram Sicras ${ }^{3}$, Antonio Hormigo ${ }^{4}$, \\ Roberto Alcázar ${ }^{5}$, Nicolás Manito ${ }^{6}$ and Manuel Botana ${ }^{7}$
}

\begin{abstract}
Background: Data about the impact of chronic kidney disease (CKD) on health care costs in Spain are scarce This study was aimed to evaluate cumulative costs and healthcare utilisation in CKD in Spain.

Methods: Observational, retrospective, population-based study, which included adults who received care for CKD between 2015 and 2019. Healthcare and medication costs were summarized on a yearly basis starting from the index date (1st January 2015), and then cumulatively until 2019.

Results: We identified 44,214 patients with CKD (year 2015: age $76.4 \pm 14.3$ years, 49.0\% women, albumin-tocreatinine ratio $362.9 \pm 176.8 \mathrm{mg} / \mathrm{g}$, estimated glomerular filtration rate $48.7 \pm 13.2 \mathrm{~mL} / \mathrm{min} / 1.73 \mathrm{~m}^{2}$ ). During the 2015-2019 period, cumulative CKD associated costs reached 14,728.4 Euros, being cardiovascular disease hospitalizations, particularly due to heart failure and CKD, responsible for $77.1 \%$ of costs. Total medication cost accounted for $6.6 \%$ of the total cost. There was a progressive decrease in cardiovascular disease hospital costs per year (from 2741.1 Euros in 2015 to 1.971.7 Euros in 2019). This also occurred with cardiovascular and diabetic medication costs, as well as with the proportion of hospitalizations and mortality. Costs and healthcare resources use were higher in the DAPA-CKD like population, but also decreased over time.

Conclusions: Between 2015 and 2019, costs of patients with CKD in Spain were high, with cardiovascular hospitalizations as the key determinant. Medication costs were responsible for only a small proportion of total CKD costs. Improving CKD management, particularly with the use of cardiovascular and renal protective medications may be helpful to reduce CKD burden.
\end{abstract}

Keywords: Chronic kidney disease, Cost, DAPA-CKD, Healthcare, Hospitalization, Medication

\section{Introduction}

Chronic kidney disease (CKD) is a common condition that affected nearly 700 million persons worldwide in 2017. However, these numbers are expected to rise due to the ageing of the population, and the increasing prevalence of hypertension and diabetes [1-3]. CKD markedly increases the risk of developing cardiovascular disease, particularly ischemic heart disease and heart failure [HF], as well as cardiovascular and all-cause

\footnotetext{
* Correspondence: escobar_cervantes_carlos@hotmail.com

${ }^{1}$ University Hospital La Paz, Madrid, Spain

Full list of author information is available at the end of the article
}

death. In addition, CKD promotes the development of end-stage renal disease [2, 4]. Remarkably, the risk of adverse outcomes increases as renal function decreases or albuminuria develops [5].

The apropriate treatment of CKD patients has been associated with a reduction in the risk of developing cardiovascular and renal complications [6]. This is particularly true with the use of renin angiotensin system inhibitors, including angiotensin-converting enzyme inhibitors (ACEi) and angiotensin-receptor blockers (ARBs) $[7,8]$, and more recently, with the use of some

C C The Author(s). 2021 Open Access This article is licensed under a Creative Commons Attribution 4.0 International License, which permits use, sharing, adaptation, distribution and reproduction in any medium or format, as long as you give appropriate credit to the original author(s) and the source, provide a link to the Creative Commons licence, and indicate if changes were made. The images or other third party material in this article are included in the article's Creative Commons licence, unless indicated otherwise in a credit line to the material. If material is not included in the article's Creative Commons licence and your intended use is not permitted by statutory regulation or exceeds the permitted use, you will need to obtain permission directly from the copyright holder. To view a copy of this licence, visit http://creativecommons.org/licenses/by/4.0/ The Creative Commons Public Domain Dedication waiver (http://creativecommons.org/publicdomain/zero/1.0/) applies to the data made available in this article, unless otherwise stated in a credit line to the data. 
sodium-glucose cotransporter-2 (SGLT-2) inhibitors [9, 10], even in the absence of type 2 diabetes (T2D) [9].

Of note, CKD represents a major and growing economic problem [3, 11, 12]. Increasing the knowledge about CKD-related costs is mandatory to ascertain how CKD management can be improved, leading to a significant decrease in CKD burden [5, 11-18]. Unfortunately, data about the impact of CKD on health care costs in Spain are scarce, and most importantly, not focused on a comprehensive approach $[19,20]$.

The aim of this study was to evaluate the cumulative costs and healthcare utilisation in CKD patients in Spain over the last 5 years, along with the epidemiological characterization of the population at index date (1st January 2015). This was also analyzed in a population who met the main inclusion criteria of the DAPA-CKD trial [9] (DAPA-CKD like population).

\section{Methods}

This was an observational cohort study, comprising cross-sectional and longitudinal retrospective analyses using secondary data captured in electronic health records from seven Spanish regions, from the BIG-PAC ${ }^{\circ}$ database. BIG-PAC ${ }^{\oplus}$ database included information from non-selected 1.7 million persons of primary health centers and referral hospitals within the Spanish national health system. Before export to BIG-PAC ${ }^{\circledR}$, data were rigorously anonymized and dissociated, making not possible individual identification. As a result, it automatically collects information from routine practice, without requiring manual inputting. Previous studies have demonstrated its representativeness of the Spanish population $[21,22]$.

This database has been validated as an information source for studies of epidemiology, therapeutic adaptation and health/non-healthcare resource use and associated costs. It is representative of the Spanish population [21]. The study was approved by the Investigation Ethics Committee of Consorci Sanitari from Terrassa. Informed consent was waived by the same ethics committee that approved the study, as this was a secondary data study and data were fully anonymized and dissociated from patients. All methods were performed in accordance with the relevant guidelines and current regulations [21,23].

The study population included all adult patients with at least one diagnostic code of CKD or having laboratory results meeting the definition of CKD prior to the index date (1st January 2015). CKD stages 1-5 were defined according to the estimated glomerular filtration rate (eGFR; estimated by the CKD-Epidemiology Collaboration equation) and the urine albumin-to-creatinine ratio (UACR), as follows: stage 1: eGFR $\geq 90 \mathrm{~mL} / \mathrm{min} /$ $1.73 \mathrm{~m}^{2}$ and UACR $\geq 30 \mathrm{mg} / \mathrm{g}$; stage 2 : eGFR $60-89 \mathrm{~mL} /$ $\mathrm{min} / 1.73 \mathrm{~m}^{2}$ and UACR $\geq 30 \mathrm{mg} / \mathrm{g}$; stage 3a: eGFR $45-59$
$\mathrm{mL} / \mathrm{min} / 1.73 \mathrm{~m}^{2}$; stage $3 \mathrm{~b}$ : eGFR $30-44 \mathrm{~mL} / \mathrm{min} / 1.73 \mathrm{~m}^{2}$; stage 4: eGFR $15-29 \mathrm{~mL} / \mathrm{min} / 1.73 \mathrm{~m}^{2}$; stage 5 : eGFR < $15 \mathrm{~mL} / \mathrm{min} / 1.73 \mathrm{~m}^{2}$ [23, 24]. T2D was defined as all adult patients filling a prescription of any antidiabetic medication, having a T2D diagnostic code or $\mathrm{HbA} 1 \mathrm{c}>7 \%$ prior to index date, excluding type 1 diabetes. The DAPACKD like population included those adult patients, with or without T2D, but not type 1 diabetes, who had an eGFR of 25 to $75 \mathrm{~mL} / \mathrm{min} / 1.73 \mathrm{~m}^{2}$ and a UACR of 200 to $5000 \mathrm{mg} / \mathrm{g}$, on stable treatment with ACEi or ARBs for at least 1 month [9].

Baseline characteristics for the overall CKD and DAPA-CKD like populations, including demographics, comorbidities and medications, were calculated at index date (1st January 2015) for the full group and by T2D status and CKD stage. The main comorbidities included myocardial infarction (MI), HF, atrial fibrillation (AF), stroke, peripheral artery disease (PAD), hyperkalemia and diabetes. A minimum of 1-year of data before index date was required. ICD-9 and ICD-10 codes (https:// eciemaps.mscbs.gob.es) were considered for the diagnosis of comorbidities (supplementary Table 1). Treatments were recorded from the registries for dispensing medicines, according to the Anatomical Therapeutic Chemical Classification System (supplementary Table 1) [25]. Treatment for hypertension/HF (ACEi, ARBs, direct renin inhibitors, aldosterone antagonists, angiotensin receptor and neprilysin inhibition, beta blockers, diuretics, calcium channel blockers), antidiabetics (SGLT2 inhibitors, metformin, sulfonylureas, dipeptidyl peptidase 4 [DPP-4] inhibitors, glucagon-like peptide-1 [GLP1] receptor agonists, meglitinides, glitazones, acarbose, miglitol, insulin), antithrombotic therapy (warfarin, aspirin, P2Y12 receptor antagonists) and statins were recorded. Prescriptions were performed according to physicians' criteria in routine practice [23].

Prevalence and incidence of CKD were also calculated at index date (1st January 2015). Incidence was calculated as all newly diagnosed patients during 2015 divided by the number of patients without CKD in the population at the beginning of 2015 and expressed in cases per 1000 patient-years. Prevalence was calculated as all patients with a CKD diagnosis at the end of 2015, divided by all individuals in the total population covered by the database at that time. The denominator included all individuals that were attended by any reason in the Spanish health care system in the previous 3 years to the index date (2012-2014). Mortality data were updated every month in the BIG-PAC database.

Costs were not taken from BIG-PAC database. Data were calculated using sources from the Spanish National Healthcare System of 2019 (supplementary Table 2) and used for the overall study period [21]. The healthcare resource use and costs and medication and procedure 
costs were summarized on a yearly basis starting from index date (1st January 2015), and then cumulatively until the end of the last year of follow-up (31st December 2019). All hospital visits (total and cardiovascular events), medical and emergency room visits, medication costs, and procedure costs (total, dialysis, kidney transplant) were included for the analysis of the annual direct healthcare costs [21]. Costs per patient were calculated every year. Patients who died during the follow-up had a cost of 0 allocated to the remaining duration of the study, whereas a patient leaving the database prior to data cut off was not included in the denominator for the time after leaving the database. No double counting occurred, as for each cost (i.e CKD hospitalizations) only that category was counted.

Annual indirect non-health costs included the number of days of productivity lost due to disability [21]. Rates were obtained from hospital accounting, except for medication and indirect costs, which were calculated as follows, respectively: a) medical prescriptions: according to the retail price per package at the time of dispensing [26]; b) costs for days of productivity lost: according to the mean interprofessional wage. The estimation of days off of work were obtained by the temporary work incapacity reported in primary care setting [27]. Hospital admission costs of cardiovascular events during follow-up were obtained taking into consideration the daily hospital rate and the number of hospital days per stay.

\section{Statistical analysis}

Categorical variables were described by their absolute (n) and relative frequencies (\%) and continuous variables by the mean and standard deviation. Categorical variables were compared with the Chi-square test and means by the $t$-student test. Analyses of health care cost were performed for the index date with 5 year of followup. The cumulative mean healthcare cost was estimated and presented on a yearly basis from the index date until last year of follow-up. Health care costs were presented per patient (mean cost). A level of statistical significance of 0.05 was applied in all the statistical tests. The data were analyzed using the statistical package SPSS v22.0 (SPSS Inc., Chicago, Illinois, USA) [21].

\section{Results}

Out of 1,7 million people included in the BIG-PAC ${ }^{\bullet}$ database in 2015, 1,3 were attended during the 20122014 period, of whom 964,862 were 18 years or older. At index date, 45.376 patients had CKD. As 1162 patients were excluded due to inconsistent data, 44,214 patients (97.4\%) comprised the CKD study population (Fig. 1). Incidence at index date was 2.06 per 1000 patient-years and the prevalence was $4.90 \%$.

\section{Total population}

$\mathrm{N}=1,712,234$

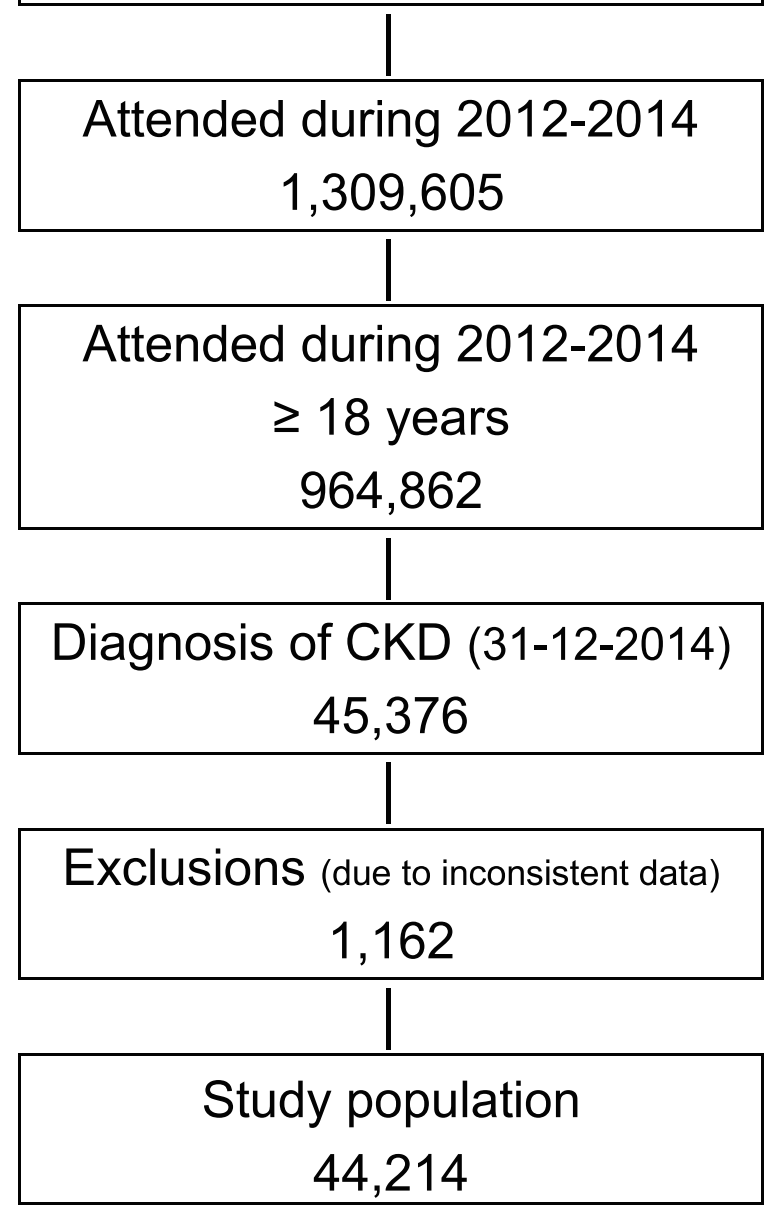

CKD: chronic kidney disease.

Fig. 1 Flowchart costs population (2015). CKD: chronic kidney disease

The baseline clinical characteristics of the CKD population according to the presence of T2D and CKD stage are presented in Table 1. Overall, mean age was $76.4 \pm$ 14.3 years, $49.0 \%$ of patients were women, mean UACR was $362.9 \pm 176.8 \mathrm{mg} / \mathrm{g}$ and mean eGFR $48.7 \pm 13.2 \mathrm{~mL} /$ $\min / 1.73 \mathrm{~m}^{2}$. Overall, $20.0 \%$ of patients had a history of HF, $15.3 \% \mathrm{MI}$, and $10.5 \%$ stroke. With regard to treatments, $71.0 \%$ were taking renin angiotensin system (RAAS) inhibitors, but only $4.4 \%$ of patients at maximal doses. A total of 19,985 (45.2\%) patients had T2D. Patients with T2D were younger $(75.8 \pm 14.0$ vs $76.4 \pm 14.1$ years; $P=0.001)$, but UACR $(391.3 \pm 189.4$ vs $347.4 \pm$ $172.3 \mathrm{mg} / \mathrm{g}, P<0.001)$, and HbA1c $(7.7 \pm 2.0$ vs $6.2 \pm$ $1.2 \% ; P<0.001)$ were higher and eGFR lower $(47.5 \pm 12.4$ vs $\left.49.6 \pm 11.3 \mathrm{~mL} / \mathrm{min} / 1.73 \mathrm{~m}^{2}, P<0.001\right)$ compared to those without T2D. Moreover, comorbidities were more 


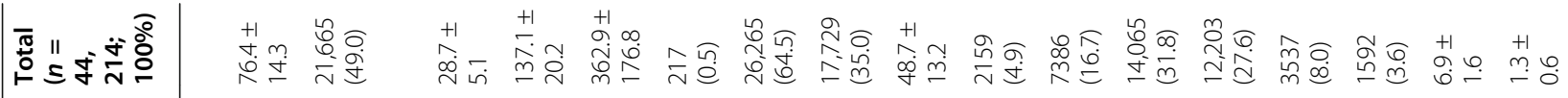

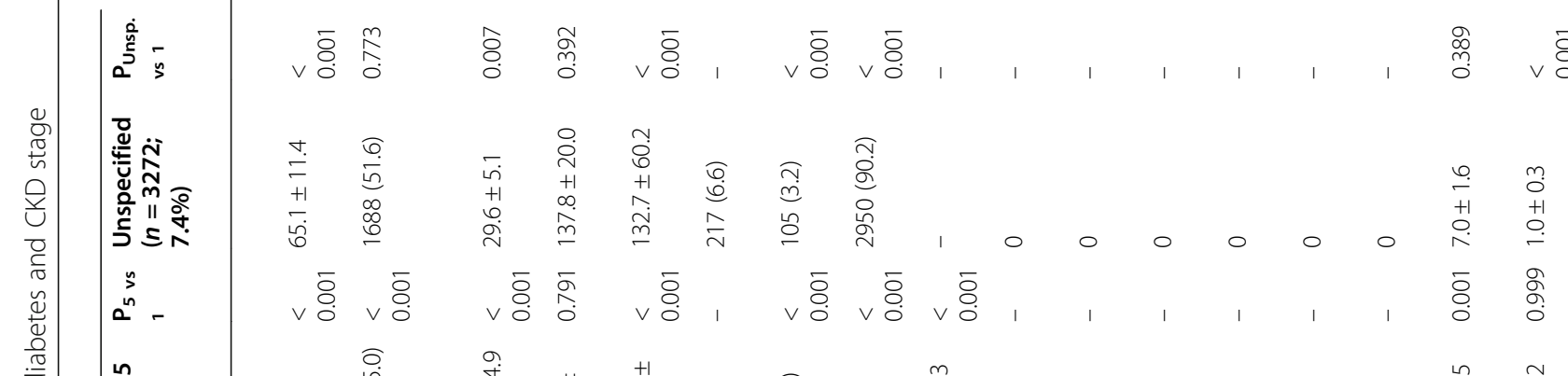

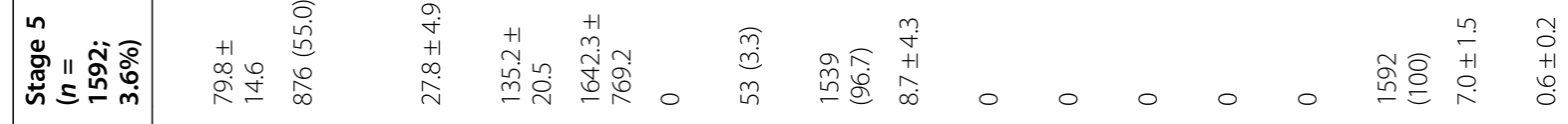

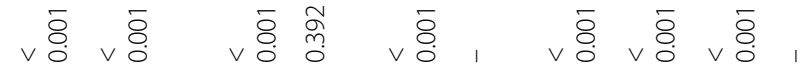
a d

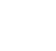

बे

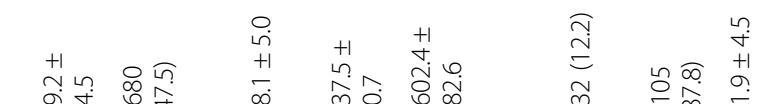

ثิ่

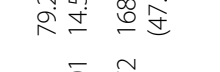

离 $v \bar{\delta} \frac{0}{0}$ (n)

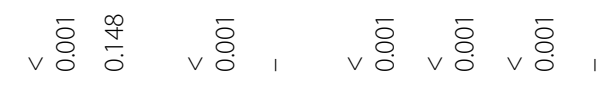

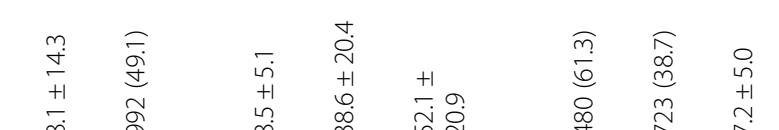

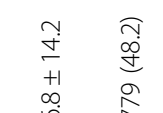

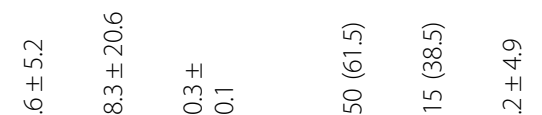
$\stackrel{0}{\circ} 6$

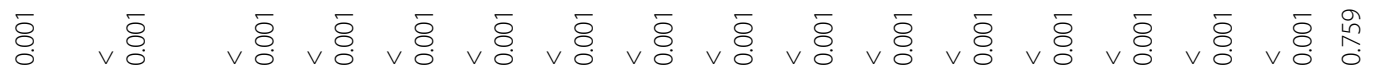




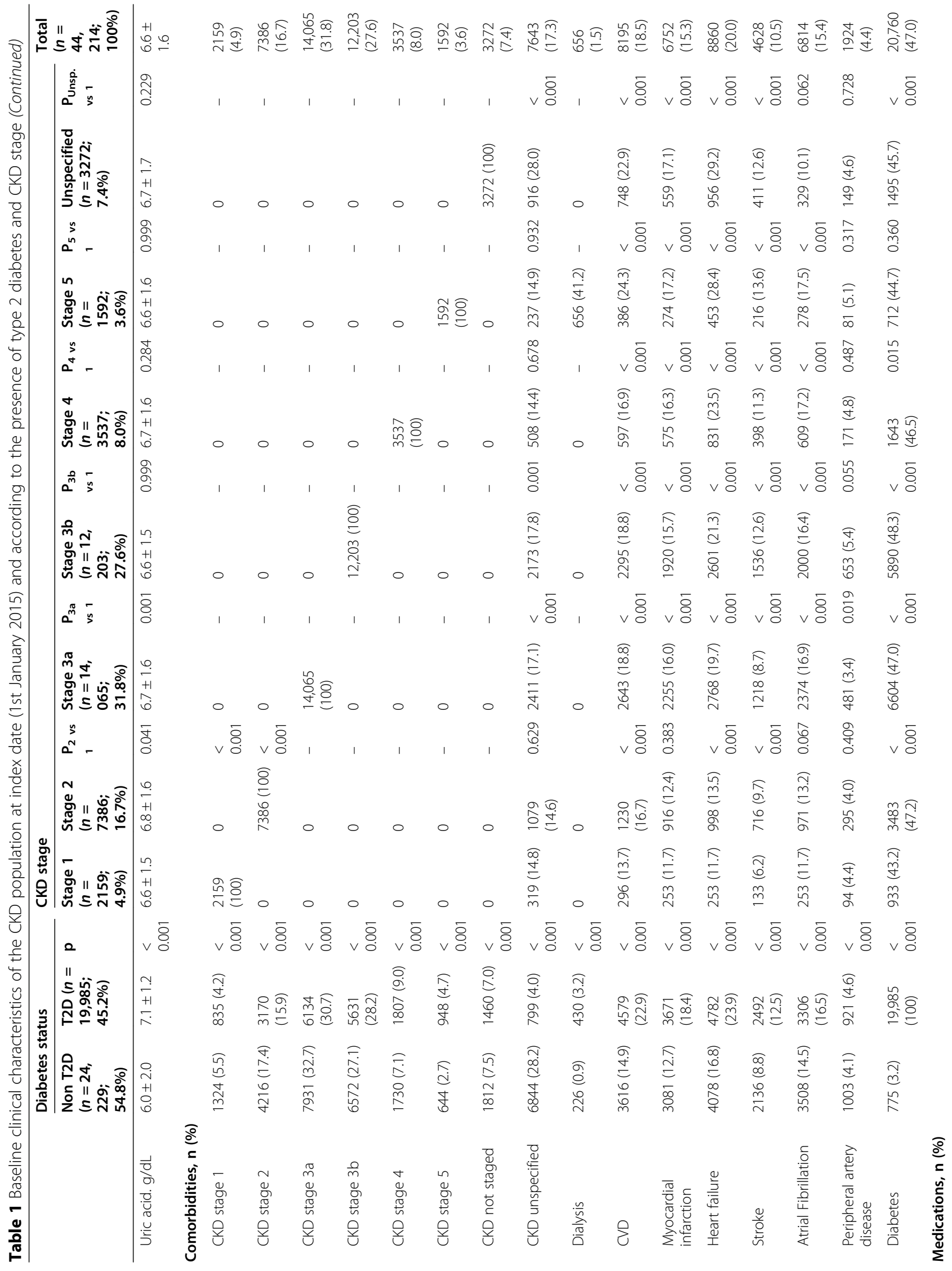




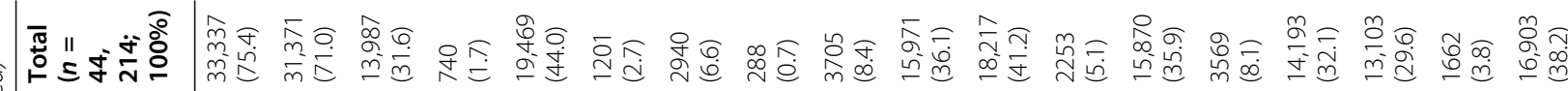
|

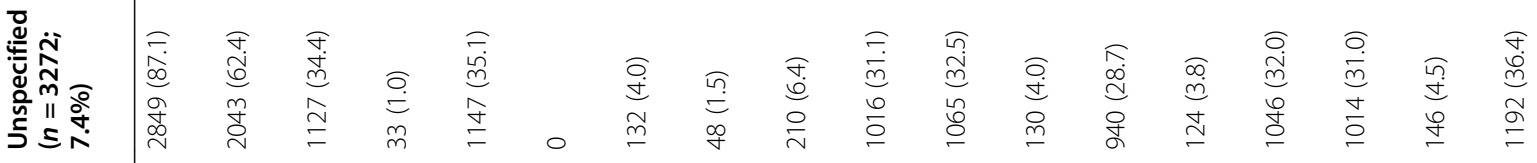

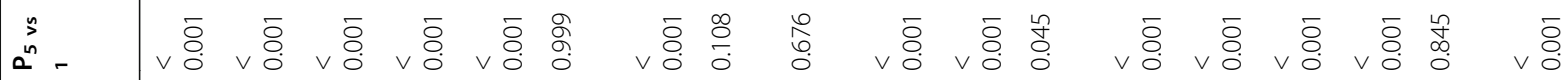

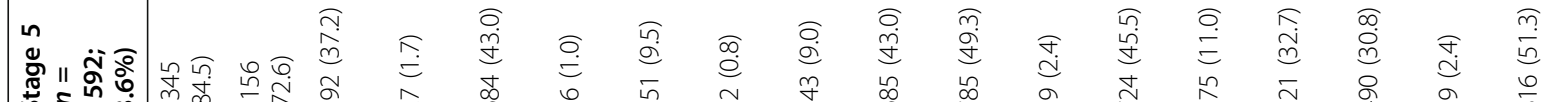

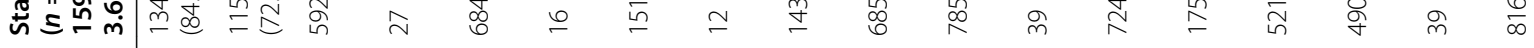
ఎ

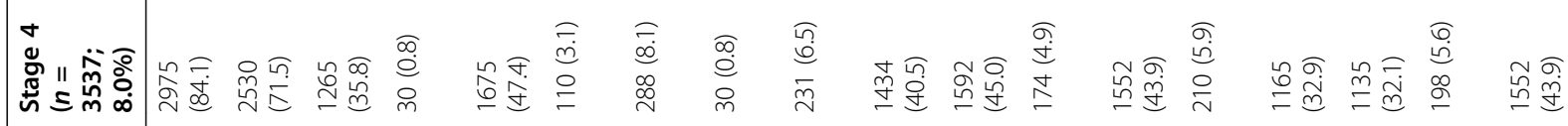
œ

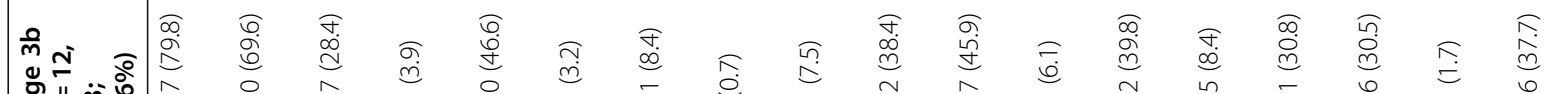

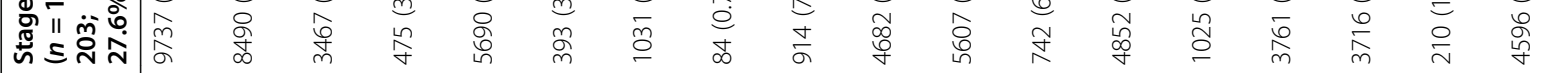

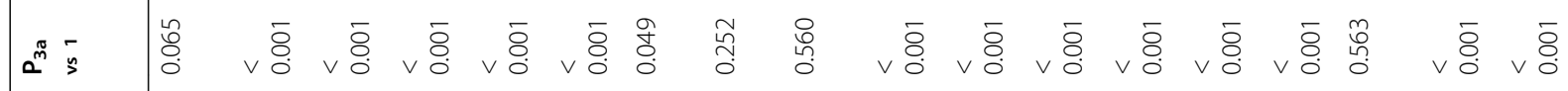

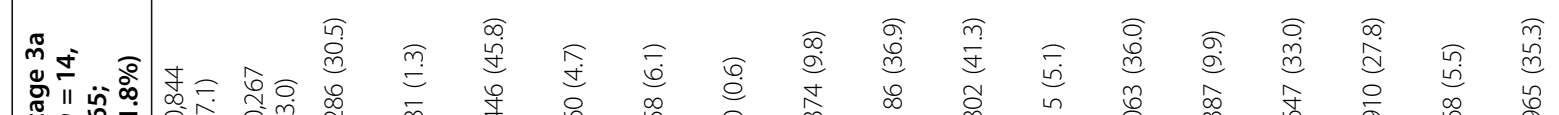

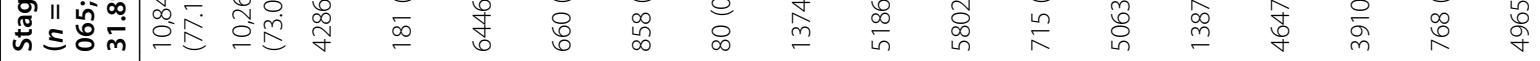

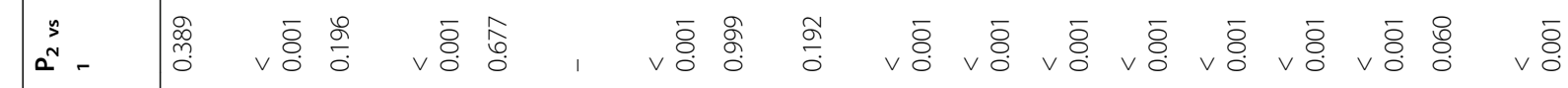

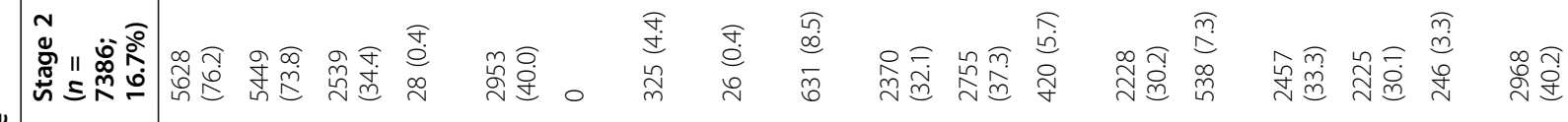

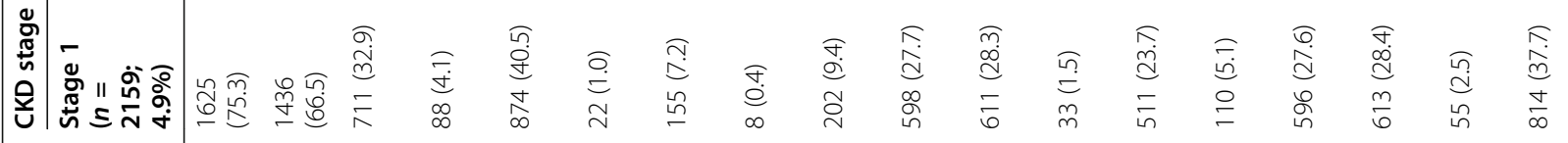

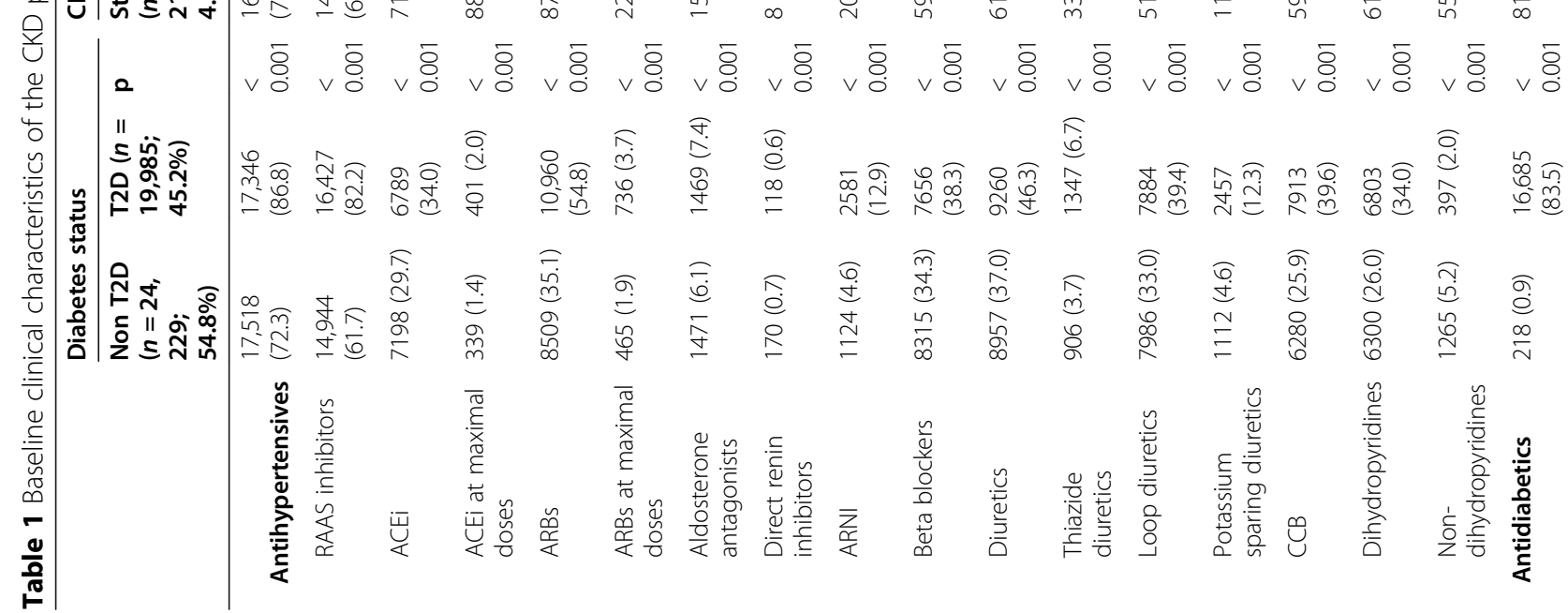




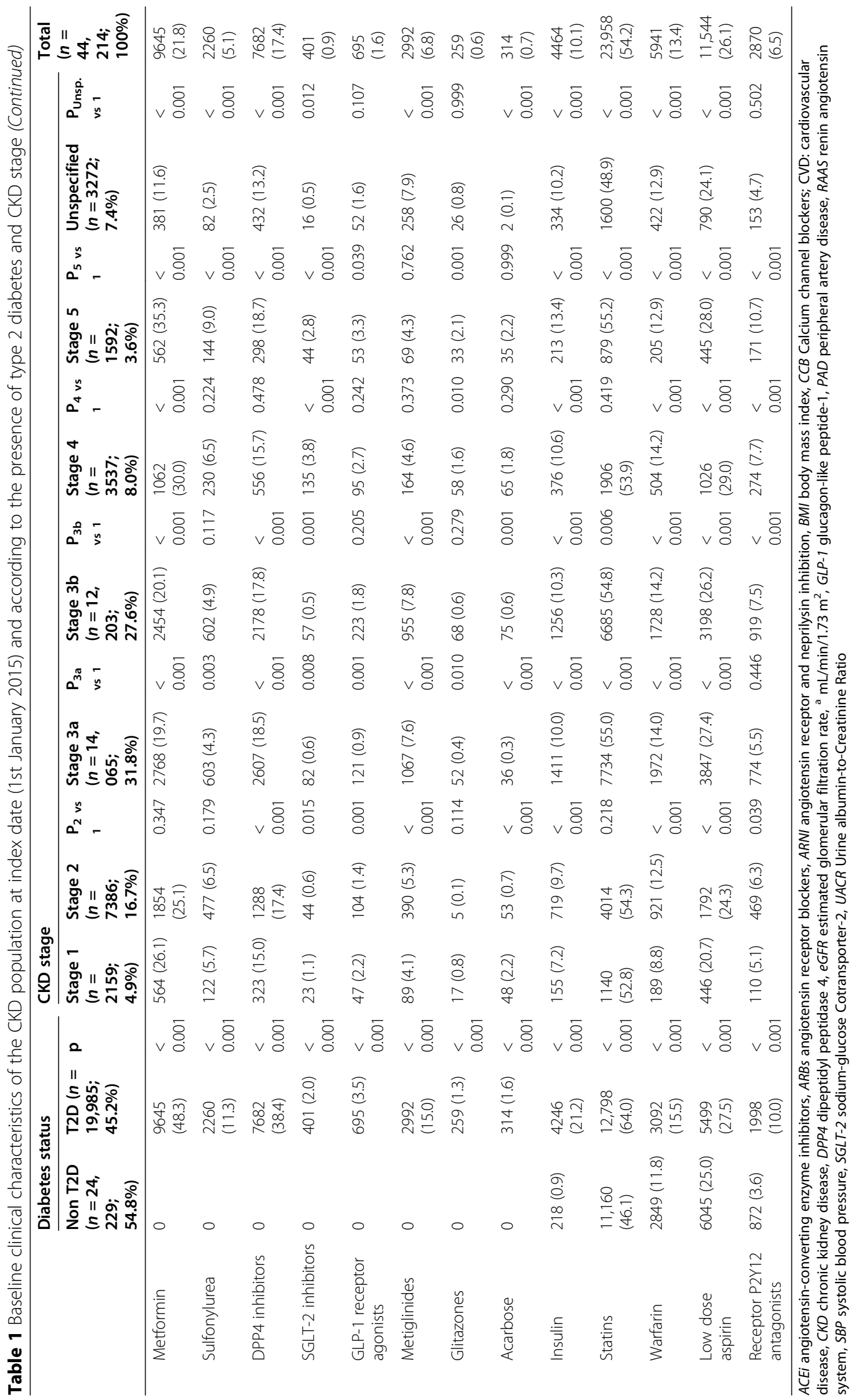


common among patients with T2D. In addition, more T2D patients were taking RAAS inhibitors $(82.2 \%$ vs $61.7 \%$; $P<0.001$ ). Overall, $71.0 \%$ of patients had stage $\geq 3$ CKD. Age increased as renal function worsened (from $69.8 \pm 14.7$ years in patients with stage 1 CKD to $79.8 \pm$ 14.6 years among stage 5 CKD patients; $P<0.001$ ), as well as UACR (from $106.8 \pm 49.8 \mathrm{mg} / \mathrm{g}$ to $1642.3 \pm 769.2$ $\mathrm{mg} / \mathrm{g} ; P<0.001)$ and the proportion of patients treated with RAAS inhibitors (from 66.5 to $72.6 \%$; $P<0.001$ ). Similarly, comorbidities increased as renal function decreased (Table 1).

Patient hospital mean costs per year are presented in Table 2. From 2015 to 2019 there was a progressive decrease in cardiovascular disease hospital cost per patient year (from 2741.1 to 1971.7 Euros) and patient cumulative cardiovascular disease hospital mean cost reached 11,349.2 Euros in 2019 (supplementary Table 3 and Fig. 2a). The great burden of hospital cost was due to cardiovascular hospitalizations, particularly HF and CKD. Regarding medications, from 2015 to 2019, diabetes drugs mean cost decreased from 102.71 to 89.99 Euros per patient and year, but HF medication mean cost slightly increased from 50.68 to 53.04 Euros, respectively (Table 2). The cumulative mean cost of diabetes and HF medications reached 503.9 and 220.6 Euros, respectively, in 2019 (supplementary Table 3 and Fig. 2b). Dialysis cost decreased from 2328.8 to 1624.2 Euros, respectively (cumulative cost of 9602.9 Euros) and kidney transplant from 655.7 to 465.2 Euros, respectively (cumulative cost of 2701.8 Euros) (supplementary Table 3 and Fig. 2c).

The health resources use for each year is shown in Table 3. The proportion of hospitalized patients decreased from $27.6 \%$ in 2015 to $21.2 \%$ in $2019 ; P<0.001$, the days for hospitalized patients from 16.4 to 11.2 days; $P<0.001$, and the proportion of patients that died from 8.7 to $4.3 \% ; P<0.001$, respectively. Total health-related cost decreased from 3561 Euros in 2015 to 2493 Euros in 2019. Including indirect costs, total cumulative patient mean costs reached 14,728.4 Euros in 2019; 651,203, 550.3 Euros per total CKD population (Table 4).

A specific analysis was performed in the DAPA-CKD like population $(n=5925)$. In this group of patients, mean age was $76.5 \pm 14.6$ years, $48.5 \%$ were women, and mean UACR was $420.7 \pm 198.8 \mathrm{mg} / \mathrm{g}$. Overall, $20.8 \%$ of patients had a history of $\mathrm{HF}, 13.4 \% \mathrm{MI}$, and $10.8 \%$ prior stroke. With regard to treatments, all patients were taking RAAS, but only $13.4 \%$ of patients at maximal doses. A total of 2951 (49.8\%) patients had T2D. Patients with T2D had higher UACR (426.3 \pm 201.5 vs $350.2 \pm 171.4$ $\mathrm{mg} / \mathrm{g} ; P<0.001)$, and HbA1c $(7.5 \pm 2.0$ vs $5.8 \pm 1.3 \%$; $P<0.001)$, but without significant differences in eGFR $\left(49.5 \pm 12.0\right.$ vs $\left.50.0 \pm 11.8 \mathrm{~mL} / \mathrm{min} / 1.73 \mathrm{~m}^{2} ; P=0.336\right)$. In addition, comorbidities were more common among patients with T2D compared to those without T2D. Overall, in the DAPA-CKD like population, $95.2 \%$ had

Table 2 Patients hospital mean cost per year ${ }^{\mathrm{a}}$

\begin{tabular}{|c|c|c|c|c|c|c|c|c|c|c|c|}
\hline & \multicolumn{2}{|l|}{2015} & \multicolumn{2}{|l|}{2016} & \multicolumn{2}{|l|}{2017} & \multicolumn{2}{|l|}{2018} & \multicolumn{2}{|l|}{2019} & \multirow{2}{*}{$\begin{array}{l}\text { Cumulative } \\
\text { cost in } \\
2019\end{array}$} \\
\hline & mean & SD & mean & SD & mean & SD & mean & SD & mean & SD & \\
\hline \multicolumn{12}{|l|}{ Total hospital cost } \\
\hline CVD & 2741.1 & 5097.5 & 2452.6 & 5049.5 & 2308.3 & 5001.4 & 1875.5 & 4953.3 & 1971.7 & 4953.3 & $11,349.2$ \\
\hline Cardiorenal & 2500.3 & 4924.3 & 2250.7 & 4654.3 & 2105.9 & 4180.7 & 1685.4 & 3412.9 & 1766.7 & 3935.4 & $10,309.0$ \\
\hline $\mathrm{HF}$ & 1514.3 & 3602.4 & 1341.9 & 3160.5 & 1283.9 & 3023.9 & 1115.0 & 2520.9 & 1012.6 & 2426.7 & 6267.7 \\
\hline CKD & 986.0 & 4.044 .9 & 908.7 & 4026.2 & 822.0 & 3860.2 & 570.4 & 2866.6 & 754.2 & 3410.9 & 4041.3 \\
\hline $\mathrm{Ml}$ & 74.3 & 732.7 & 61.6 & 589.2 & 55.0 & 516.1 & 55.3 & 560.2 & 65.4 & 596.4 & 311.5 \\
\hline Stroke & 111.7 & 784.8 & 99.4 & 754.1 & 105.4 & 792.1 & 94.6 & 732.0 & 99.8 & 749.0 & 510.9 \\
\hline PAD & 54.9 & 658.9 & 41.0 & 506.8 & 42.0 & 544.6 & 40.2 & 521.5 & 39.7 & 551.9 & 217.8 \\
\hline \multicolumn{12}{|l|}{ Medication cost } \\
\hline Total medication & 181.80 & 384.70 & 178.83 & 382.2 & 180.97 & 352.0 & 142.66 & 249.7 & 167.76 & 323.0 & 852.0 \\
\hline Diabetes medication & 102.71 & 341.10 & 99.81 & 348.0 & 128.51 & 443.6 & 82.84 & 291.7 & 89.99 & 291.5 & 503.9 \\
\hline HF medication & 50.68 & 76.76 & 47.34 & 72.4 & 31.88 & 53.2 & 37.71 & 60.4 & 53.04 & 93.4 & 220.6 \\
\hline CVD medication & 28.41 & 62.40 & 31.68 & 71.7 & 20.58 & 46.1 & 22.11 & 45.6 & 24.73 & 53.0 & 127.5 \\
\hline \multicolumn{12}{|l|}{ Procedure costs } \\
\hline Total procedures & 2984.5 & $23,547.4$ & 2657.5 & $21,616.1$ & 2516.5 & $20,106.6$ & 2056.8 & $15,954.3$ & 2089.4 & $16,415.2$ & $12,304.7$ \\
\hline Dialysis & 2328.8 & $22,021.0$ & 2081.3 & $19,672.1$ & 1965.2 & $18,523.3$ & 1603.4 & $15,265.7$ & 1624.2 & $15,465.8$ & 9602.9 \\
\hline Kidney transplant & 655.7 & 4720.9 & 576.2 & 4026.3 & 551.3 & 3898.3 & 453.4 & 3.267 .1 & 465.2 & 3402.9 & 2701.8 \\
\hline
\end{tabular}

CVD cardiovascular disease, $H F$ heart failure, $C K D$ chronic kidney disease, $M I$ myocardial infarction, $P A D$ peripheral artery disease

${ }^{a}$ In Euros. Cardiorenal disease includes HF and CKD 


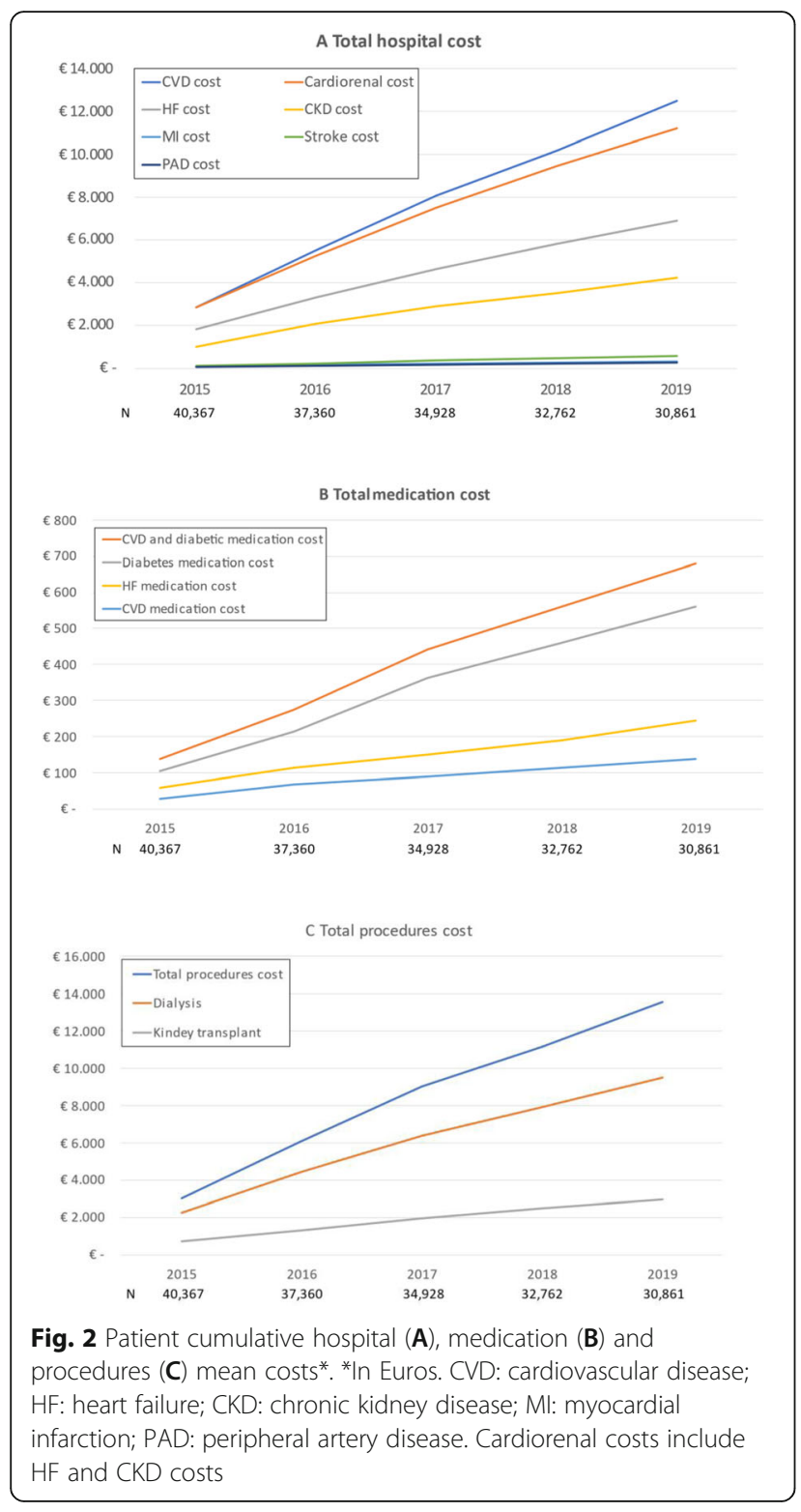

stage 3 or 4 CKD. UACR increased as renal function worsened (from $127.9 \pm 58.5$ in patients with stage 2 CKD to $1689.3 \pm 841.3 \mathrm{mg} / \mathrm{g}$ among stage 4 CKD patients; $P<0.001$ ), as well as comorbidities. In addition, the proportion of patients at maximal doses of ACEi or ARBs also increased as stage CKD worsened (from $10.3 \%$ in patients with stage 2 CKD to $17.2 \%$ among stage $4 \quad$ CKD patients; $P<0.001$ ) (supplementary Table 4).

With regard to patients hospital mean cost per year in the DAPA-CKD like population, there was a progressive decrease in cardiovascular disease hospital cost per year (from 3025.9 Euros in 2015 to 2022.9 Euros in 2019). Overall, patient cumulative cardiovascular disease hospital mean cost reached 12,219.0 Euros in 2019. The great burden of this cost was due to cardiovascular hospitalizations, particularly HF and CKD. Regarding medications, from 2015 to 2019, diabetes drugs mean cost decreased from 103.7 to 99.0 Euros and HF medication mean cost from 57.8 to 53.0 Euros, respectively. The cumulative mean cost of diabetes and HF medications reached 560.2 and 242.8 Euros, respectively, in 2019. Dialysis cost decreased from 2282.2 to 1591.7 Euros, respectively (cumulative cost of 9501.3 Euros) and kidney transplant from 727.8 to 502.4 Euros, respectively (cumulative cost of 2973.4 Euros) (supplementary Table 5).

\section{Discussion}

Our data showed that in Spain, during the 2015-2019 period, CKD-associated costs were substantial, being cardiovascular hospitalizations the most important contributing factor (77.1\%), mainly HF and CKD hospitalizations; however, medication cost contribution was marginal (6.6\%). Of note, the annual cardiovascular hospitalization mean cost and mortality progressively decreased over time.

In our study, the prevalence of CKD was nearly 5\% (mean age 76 years; $71 \%$ stage $\geq 3 \mathrm{CKD}$ ). Previously performed studies in Spain have shown a higher prevalence of CKD, possibly due to differences in the inclusion criteria, the methods for renal function determination and the study design. Since this is database study, patients with CKD risk factors (such as diabetes mellitus, hypertension or cardiovascular disease, who are not regularly screened and therefore identified) cannot be reflected, showing the high underdiagnosis rate of CKD still present nowadays. Additionally, this difference in CKD prevalence might be a consequence of a higher use of CKD protective treatments [23, 28-30]. Despite the fact that $71 \%$ of patients were taking RAAS inhibitors $(82 \%$ among T2D patients) in our study, only $4.4 \%$ of patients reached maximal doses, suggesting that there is still a potential benefit on CKD outcomes with uptitration). It is likely that the risk of hyperkalemia or renal function impairment associated with these drugs, mainly in elderly patients or in advanced CKD could have had some impact on these results [31]. However, these numbers were not significantly higher in stage 1-2 CKD patients. As it has been reported that achieving maximal doses of RAAS inhibitors (vs lower doses) may be associated with better outcomes, it is highly recommended the use of cardiovascular and renal protective drugs at adequate doses to reduce outcomes [32,33]. The reduction in the proportion of hospitalized patients, days of hospitalization and mortality during the 2015-2019 period could be related with a better comprehensive management of CKD population, including the use of guidelines recommended drugs [33-36]. 
Table 3 Health resources use for each year per patient

\begin{tabular}{|c|c|c|c|c|c|c|c|c|c|c|c|c|c|c|c|c|}
\hline & \multicolumn{2}{|l|}{2015} & \multicolumn{2}{|l|}{2016} & \multirow{2}{*}{$\begin{array}{l}P_{2016-} \\
2015\end{array}$} & \multicolumn{2}{|l|}{2017} & \multirow{2}{*}{$\begin{array}{l}P_{2017-} \\
2015\end{array}$} & \multicolumn{2}{|l|}{2018} & \multirow{2}{*}{$\begin{array}{l}P_{2018-} \\
2015\end{array}$} & \multicolumn{2}{|l|}{2019} & \multirow{2}{*}{$\begin{array}{l}P_{2019-} \\
2015\end{array}$} & \multicolumn{2}{|l|}{ Total } \\
\hline & mean & SD & mean & SD & & mean & SD & & mean & SD & & mean & SD & & mean & SD \\
\hline Primary care visits & 12.4 & 14.8 & 10.6 & 12.3 & $\begin{array}{l}< \\
0.001\end{array}$ & 9.2 & 10.4 & $\begin{array}{l}< \\
0.001\end{array}$ & 8.4 & 9.6 & $\begin{array}{l}< \\
0.001\end{array}$ & 7.5 & 8.3 & $\begin{array}{l}< \\
0.001\end{array}$ & 48.1 & 55.8 \\
\hline Specialized care visits & 1.9 & 4.1 & 1.1 & 4.3 & $\begin{array}{l}< \\
0.001\end{array}$ & 1.0 & 4.2 & $\begin{array}{l}< \\
0.001\end{array}$ & 0.9 & 4.1 & $\begin{array}{l}< \\
0.001\end{array}$ & 0.7 & 3.9 & $\begin{array}{l}< \\
0.001\end{array}$ & 5.6 & 7.2 \\
\hline Emergency room visits & 0.7 & 2.3 & 0.6 & 2.6 & $\begin{array}{l}< \\
0.001\end{array}$ & 0.5 & 2.1 & $\begin{array}{l}< \\
0.001\end{array}$ & 0.5 & 2.1 & $\begin{array}{l}< \\
0.001\end{array}$ & 0.4 & 1.9 & $\begin{array}{l}< \\
0.001\end{array}$ & 2.7 & 4.5 \\
\hline Laboratory requests & 0.8 & 1.2 & 0.7 & 1.5 & $\begin{array}{l}< \\
0.001\end{array}$ & 0.7 & 1.5 & $\begin{array}{l}< \\
0.001\end{array}$ & 0.6 & 1.4 & $\begin{array}{l}< \\
0.001\end{array}$ & 0.6 & 1.3 & $\begin{array}{l}< \\
0.001\end{array}$ & 3.4 & 5.1 \\
\hline Radiology and other tests & 0.6 & 1.3 & 0.6 & 1.3 & - & 0.6 & 1.4 & - & 0.7 & 1.5 & $\begin{array}{l}< \\
0.001\end{array}$ & 0.7 & 1.5 & $\begin{array}{l}< \\
0.001\end{array}$ & 3.2 & 4.2 \\
\hline \multicolumn{17}{|l|}{ Hospitalization } \\
\hline - Days (all patients) & 5.7 & 10.6 & 5.1 & 10.5 & $\begin{array}{l}< \\
0.001\end{array}$ & 4.8 & 10.4 & $\begin{array}{l}< \\
0.001\end{array}$ & 3.9 & 10.3 & $\begin{array}{l}< \\
0.001\end{array}$ & 4.1 & 10.3 & $\begin{array}{l}< \\
0.001\end{array}$ & 23.6 & 37.6 \\
\hline - Hospitalized patients, n (\%) & \multicolumn{2}{|l|}{$\begin{array}{l}12,203 \\
(27.6)\end{array}$} & \multicolumn{2}{|c|}{$\begin{array}{l}10,832 \\
(24.5)\end{array}$} & $\begin{array}{l}< \\
0.001\end{array}$ & \multicolumn{2}{|c|}{$10,081(22.8)$} & $\begin{array}{l}< \\
0.001\end{array}$ & \multicolumn{2}{|c|}{$9727(22.0)$} & $\begin{array}{l}< \\
0.001\end{array}$ & \multicolumn{2}{|c|}{$9373(21.2)$} & $\begin{array}{l}< \\
0.001\end{array}$ & \multicolumn{2}{|c|}{$\begin{array}{l}19,108 \\
(43.2)\end{array}$} \\
\hline $\begin{array}{l}\text { - Days (for patients } \\
\text { hospitalized) }\end{array}$ & 16.4 & 10.6 & 16.5 & 10.6 & 0.161 & 16.7 & 10.70 & $\begin{array}{l}< \\
0.001\end{array}$ & 16.8 & 11.0 & $\begin{array}{l}< \\
0.001\end{array}$ & 17.0 & 11.2 & $\begin{array}{l}< \\
0.001\end{array}$ & 4.2 & 23.6 \\
\hline \multicolumn{17}{|c|}{ - Frequency of hospitalization, n (\%) } \\
\hline 0 & \multicolumn{2}{|l|}{$\begin{array}{l}32,011 \\
(72.4)\end{array}$} & \multicolumn{2}{|c|}{$\begin{array}{l}32,497 \\
(73.5)\end{array}$} & $\begin{array}{l}< \\
0.001\end{array}$ & \multicolumn{2}{|c|}{$33,515(75.8)$} & $\begin{array}{l}< \\
0.001\end{array}$ & \multicolumn{2}{|c|}{$\begin{array}{l}34,089 \\
(77.1)\end{array}$} & $\begin{array}{l}< \\
0.001\end{array}$ & \multicolumn{2}{|c|}{$\begin{array}{l}34,398 \\
(77.8)\end{array}$} & $\begin{array}{l}< \\
0.001\end{array}$ & \multicolumn{2}{|c|}{$\begin{array}{l}25,106 \\
(57.0)\end{array}$} \\
\hline 1 & \multicolumn{2}{|l|}{$\begin{array}{l}10,302 \\
(23.3)\end{array}$} & \multicolumn{2}{|c|}{$9904(22.4)$} & 0.001 & \multicolumn{2}{|c|}{$8754(19.8)$} & $\begin{array}{l}< \\
0.001\end{array}$ & \multicolumn{2}{|c|}{$8091(18.3)$} & $\begin{array}{l}< \\
0.001\end{array}$ & \multicolumn{2}{|c|}{$7783(17.6)$} & $\begin{array}{l}< \\
0.001\end{array}$ & \multicolumn{2}{|c|}{$6986(15.8)$} \\
\hline 2 & $1636(3$ & & 1680 & & 0.434 & $1724(3$ & & 0.12 & 1769 & 4.0) & 0.02 & 1724 & 3.9) & 0.12 & 5261 & 11.9) \\
\hline $3+$ & $265(0$ & & $133(0$ & & $\begin{array}{l}< \\
0.001\end{array}$ & $221(0.5$ & & 0.044 & $265(0$ & & 0.999 & $309(0$ & & 0.064 & 6862( & 15.5) \\
\hline Disability & & & & & & & & & & & & & & & & \\
\hline Days of disability & 0.3 & 4.2 & 0.3 & 4.5 & - & 0.4 & 5.6 & 0.003 & 0.4 & 5.9 & 0.004 & 0.4 & 5.9 & 0.004 & 1.9 & 17.5 \\
\hline $\begin{array}{l}\text { Average days of sick leave } \\
\text { (disability only) }\end{array}$ & 41.3 & 42.3 & 42.4 & 43.6 & $\begin{array}{l}< \\
0.001\end{array}$ & 45.3 & 46.5 & $\begin{array}{l}< \\
0.001\end{array}$ & 44.2 & 47.1 & $\begin{array}{l}< \\
0.001\end{array}$ & 46.1 & 47.6 & $\begin{array}{l}< \\
0.001\end{array}$ & 60.3 & 63.4 \\
\hline Patients with disability, n (\%) & $354(0$. & & $354(0$ & & - & $398(0$. & & 0.105 & $442(1$ & & 0.002 & $398(0$ & & 0.105 & 1326 & 3.0) \\
\hline Mortality, n (\%) & $3847(\varepsilon$ & & 3007 & & $\begin{array}{l}< \\
0.001\end{array}$ & $2432(5$ & & $\begin{array}{l}< \\
0.001\end{array}$ & 2166 & & $\begin{array}{l}< \\
0.001\end{array}$ & 1901 & & $\begin{array}{l}< \\
0.001\end{array}$ & $\begin{array}{l}13,353 \\
(30.2)\end{array}$ & \\
\hline $\begin{array}{l}\text { Patients alive at the end of the } \\
\text { year, } n\end{array}$ & 40,367 & & 37,360 & & - & 34,928 & & - & 32,762 & & - & 30,861 & & - & - & \\
\hline
\end{tabular}

Table 4 Total mean cost for year and cumulative cost in 2019 per patient

\begin{tabular}{|c|c|c|c|c|c|c|c|c|c|c|c|}
\hline & \multicolumn{2}{|l|}{2015} & \multicolumn{2}{|l|}{2016} & \multicolumn{2}{|l|}{2017} & \multicolumn{2}{|l|}{2018} & \multicolumn{2}{|l|}{2019} & \multirow{2}{*}{$\begin{array}{l}\text { Cumulative } \\
\text { cost in } \\
2019\end{array}$} \\
\hline & mean & SD & mean & SD & mean & SD & mean & SD & mean & SD & \\
\hline Primary care visits & 300.1 & 358.2 & 256.5 & 297.7 & 222.6 & 251.7 & 203.3 & 232.3 & 181.5 & 200.9 & 1164.0 \\
\hline Laboratory requests & 25.8 & 38.8 & 22.6 & 48.5 & 22.6 & 48.5 & 19.4 & 45.2 & 19.4 & 42.0 & 109.8 \\
\hline Radiology and other tests & 17.1 & 37.1 & 17.1 & 37.1 & 17.1 & 39.9 & 20.0 & 42.8 & 20.0 & 42.8 & 91.2 \\
\hline Specialized visits & 179.6 & 387.5 & 104.0 & 406.4 & 94.5 & 396.9 & 85.1 & 387.5 & 66.2 & 368.6 & 529.2 \\
\hline Emergency room visits & 83.0 & 272.6 & 71.1 & 308.1 & 59.3 & 248.9 & 59.3 & 248.9 & 47.4 & 225.2 & 320.0 \\
\hline Hospitalization & 2741.1 & 5097.5 & 2452.6 & 5049.5 & 2308.3 & 5001.4 & 1875.5 & 4.953 .3 & 1971.7 & 4.953 .3 & $11,349.2$ \\
\hline Medication & 214.1 & 421.4 & 198.7 & 415.6 & 185.3 & 413.5 & 184.3 & 421.4 & 186.8 & 443.6 & 969.2 \\
\hline Health-related cost & 3561 & 5492 & 3123 & 5276 & 2910 & 5128 & 2447 & 4516 & 2493 & 4628 & 14.532 .6 \\
\hline Indirect Cost/Sick Leave & 33 & 423 & 34 & 455 & 41 & 564 & 45 & 593 & 42 & 599 & 195.8 \\
\hline Total Cost & 3594 & 5915 & 3157 & 5731 & 2951 & 5691 & 2491 & 5109 & 2535 & 5227 & $14,728.4$ \\
\hline
\end{tabular}


More recently, the CREDENCE and DAPA-CKD trials have shown that among CKD patients with T2D, the use of SGLT-2 inhibitors translates into better cardiovascular and renal outcomes $[9,10]$. In addition, the DAPACKD and the DECLARE-TIMI 58 trials have demonstrated that the beneficial effect of dapagliflozin on the development of cardiovascular and renal complications can be extended to the CKD population without T2D, and to T2D individuals with normal renal function at baseline, respectively $[9,34]$. These data suggest that the addition of these drugs to the treatment of CKD patients could reduce even more morbidity and mortality, and consequently, overall CKD burden.

Our study showed that total cumulative cost of CKD patients was high. This has also been confirmed by previous studies [11-18]. The most important contributors for total health care cost in CKD patients were cardiovascular hospitalizations (admissions and hospital stay), particularly HF and CKD hospitalizations. This is not surprising, as CKD is associated with an increased risk of cardiovascular death, and progression to end-stage renal disease [37, 38]. There is a close relationship between CKD and HF. Thus, the presence of one condition promotes the development of the other, and vice versa [39]. In fact, HF can be an early complication of CKD. This has also been observed in the overall T2D population [39]. In the last years, a number of clinical trials have demonstrated the marked benefits of treatment with SGLT-2 inhibitors in the reduction of HF hospitalizations among T2D population [40]. Similarly, SGLT-2 inhibitors substantially decrease kidney composite outcomes in patients with T2D [41]. Unfortunately, in our study, only $2 \%$ of patients with T2D were taking SGLT-2 inhibitors at index date since this was 2015 and SGLT-2 inhibitors had been recently launched. It is very likely that the higher use of these drugs in T2D and non T2D populations will translate into a reduction of cardiovascular and renal complications and secondarily to a decrease of health care related costs $[42,43]$.

Different studies have shown that health care costs increase as renal function worsens or albuminuria develops, particularly in patients that finally require kidney replacement therapy $[5,11-14,16,20,44-46]$. As a result, although renal replacement therapy has been the object of constant analysis in order to improve the efficiency and sustainability, the fact is that preventing the occurrence and progression of CKD is the best way to reduce health care resource consumption and health care costs. Therefore, interventions designed to minimize decline in progressive kidney function, particularly among patients with stage 3 or $4 \mathrm{CKD}$, may reduce the economic CKD burden [5, 11-14, 16, 20, 44-47]. It has been reported that the addition of RAAS inhibitors to prevent the advance of nephropathy is worthwhile not only from a clinical perspective, but also from an economic point of view, even in patients with end stage renal disease, mainly driven by a reduction of hospitalization costs $[47,48]$. Both, the CREDENCE and the DAPA-CKD trials showed that among CKD patients, the use of SGLT-2 inhibitors could prevent or delay the development of kidney complications, including endstage renal disease $[9,10]$. Our data showed a progressive reduction of costs associated with dialysis and kidney transplant. Although this is hopeful, a higher use of renal protective drugs, including RAAS inhibitors and SGLT-2 inhibitors with proven renal benefit, could provide additional benefits, including health care costs reduction.

Other contributors to total CKD cost included primary care visits, specialized visits, and diagnostic tests. It has been reported that not only the costs of specialized care decrease with the length of hospital stay reduction [19], but also a nephrologist/nurse-based multifaceted intervention for stage 3 to 4 CKD patients may be a cost effective approach [49], suggesting that an integrated management of CKD patients in both specialist and primary care settings is warranted to reduce CKD burden.

In our study, cardiovascular outcomes were more common in the DAPA-CKD like subpopulation than in the general CKD population [23], translating into higher costs. This has been confirmed in a real-world population similar to that of DAPA-CKD [50]. Despite the beneficial effects shown in the DAPA-CKD trial with dapagliflozin on the prevention of cardiovascular and renal outcomes in CKD patients, regardless the presence of T2D [9], in our study, less than $4 \%$ of T2D patients from the DAPA-CKD like subpopulation were taking SGLT-2 inhibitors [50]. As a result, it would be desirable a higher use of these drugs in this population with the double aim of decreasing outcomes and health care costs.

\section{Limitations}

As this study had a retrospective design, only indirect causality may be suggested. In addition, some relevant data, such as albuminuria could not be documented in all patients, leading to an underdiagnosis of CKD. However, this is the best design to ascertain the therapeutic management of patients and health care costs in clinical practice, as no specific intervention was required to be included. Furthermore, the high number of patients included, as well as the robustness of the data allow achieving the objectives of the study. Unfortunately, medications were only recorded at baseline and no direct association can be determined between the decrease of events and costs and the use of cardiovascular medications. On the other hand, patients without a CKD diagnosis who met the definition of CKD stage 1 or 
higher were also considered as CKD patients and selected for the study. Although multiple readings of the eGFR are required to define CKD, due to the characteristics of the study, only one measurement was considered. However, the later represented only $6.9 \%$ of the total CKD study population and it was not expected that this had a significant impact on the results. Costs were taken from the Spanish National Healthcare System of 2019 and used for the overall study period. Although this could be a limitation, changes in costs during this time were marginal. In addition, improvements in efficiencies in hospital process may also reduce costs. Unfortunately, this could not be determined. Finally, although data came from seven Spanish regions, previous studies have shown that these data are representative of the entire Spanish population [21].

\section{Conclusions}

During the period 2015-2019, costs of patients with CKD in Spain were substantial, with cardiovascular hospitalizations being the key determinant, particularly in HF with CKD. Medication costs were responsible for only a small proportion of total CKD costs. Costs and healthcare resources use were even higher in the DAPACKD like population. Improving CKD management, particularly with the use of cardiovascular and renal protective medications may be helpful to reduce CKD burden.

\section{Abbreviations}

ACEi: Angiotensin-converting enzyme inhibitors; ARBs: Angiotensin-receptor blockers; AF: Atrial fibrillation; CKD: Chronic kidney disease; eGFR: estimated glomerular filtration rate; HF: Heart failure; MI: Myocardial infarction; PAD: Peripheral artery disease; RAAS: Renin angiotensin aldosterone system; SGLT-2: Sodium-glucose cotransporter-2; T2D: Type 2 diabetes; UACR: Urine albumin-to-creatinine ratio

\section{Supplementary Information}

The online version contains supplementary material available at https://doi. org/10.1186/s12913-021-06566-2.

Additional file 1: Supplementary table 1. Definition of variables.

Supplementary table 2. Description of costs / units (year 2019).

Supplementary table 3. Patient cumulative hospital mean cost*.

Supplementary table 4. Baseline clinical characteristics of the DAPACKD population at index date (1st January 2015) and according to the presence of type 2 diabetes and CKD stage. Supplementary table $\mathbf{5}$. DAPA-CKD patients hospital mean cost for year and cumulative cost in 2019*

\section{Acknowledgements}

None.

\section{Authors' contributions}

$\mathrm{CE}, \mathrm{BP}, \mathrm{UA}, \mathrm{MC}, \mathrm{AS}, \mathrm{ArS}, \mathrm{AH}, \mathrm{RA}, \mathrm{NM}$, and $\mathrm{MB}$ have all contributed to the study design, result review, manuscript preparation and final approval of the manuscript.

\section{Funding}

This study was fully funded by AstraZeneca.

\section{Availability of data and materials}

The data that support the findings of this study are available from BIG PAC but restrictions apply to the availability of these data, which were used under license for the current study, and so are not publicly available. Data are however available from the authors upon reasonable request and with permission of BIG PAC .

\section{Declarations}

Ethics approval and consent to participate

The study was approved by the Investigation Ethics Committee of Consorci Sanitari from Terrassa. Informed consent was waived by the same ethics committee that approved the study, as this was a secondary data study and data were fully anonymized and dissociated from patients. All methods were performed in accordance with the relevant guidelines and current regulations.

\section{Consent for publication}

Not applicable.

\section{Competing interests}

None.

\section{Author details}

${ }^{1}$ University Hospital La Paz, Madrid, Spain. ${ }^{2}$ AstraZeneca Farmacéutica Spain, SA, Barcelona, Spain. ${ }^{3}$ Health Economics and Outcomes Research, Atrys Health, Barcelona, Spain. ${ }^{4}$ Primary care center Salud Puerta Blanca, Malaga, Spain. ${ }^{5}$ University hospital Infanta Leonor, Madrid, Spain. ${ }^{6}$ Hospital de Bellvitge, Hospitalet de Llobregat, Barcelona, Spain. ${ }^{7}$ Hospital Universitario Lucus Augusti, Lugo, Spain.

Received: 8 March 2021 Accepted: 20 May 2021

Published online: 01 June 2021

\section{References}

1. GBD Chronic Kidney Disease Collaboration. Global, regional, and national burden of chronic kidney disease, 1990-2017: a systematic analysis for the global burden of Disease study 2017. Lancet. 2020;395:709-33.

2. Webster AC, Nagler EV, Morton RL, Masson P. Chronic kidney disease. Lancet. 2017;389(10075):1238-52. https://doi.org/10.1016/S0140-6736(16)32 064-5.

3. Abubakar II, Tillmann T, Banerjee A. Global, regional, and national age-sex specific all-cause and cause-specific mortality for 240 causes of death, 19902013: a systematic analysis for the global burden of Disease study 2013. Lancet. 2014;385:117-71.

4. Brück K, Stel VS, Gambaro G, Hallan S, Völzke H, Ärnlöv J. Et al; European CKD burden consortium. CKD prevalence varies across the European general population. J Am Soc Nephrol. 2016;27(7):2135-47. https://doi.org/1 0.1681/ASN.2015050542.

5. Darlington O, Dickerson C, Evans M, McEwan P, Sörstadius E, Sugrue D, et al Costs and healthcare resource use associated with risk of cardiovascular morbidity in patients with chronic kidney Disease: evidence from a systematic literature review. Adv Ther. 2021;38(2):994-1010. https://doi.org/1 0.1007/s12325-020-01607-4.

6. Kidney Disease: Improving Global Outcomes (KDIGO) Diabetes Work Group. KDIGO 2020 Clinical Practice Guideline for Diabetes Management in Chronic Kidney Disease. Kidney Int. 2020;98(4S):S1-S115.

7. Ruggenenti P, Perna A, Gherardi G, Garini G, Zoccali C, Salvadori M, et al. Renoprotective properties of ACE-inhibition in non-diabetic nephropathies with non-nephrotic proteinuria. Lancet. 1999;354(9176):359-64. https://doi. org/10.1016/50140-6736(98)10363-X.

8. Lewis EJ, Hunsicker LG, Clarke WR, Berl T, Pohl MA, Lewis JB, et al. Renoprotective effect of the angiotensin- receptor antagonist irbesartan in patients with nephropathy due to type 2 diabetes. N Engl J Med. 2001; 345(12):851-60. https://doi.org/10.1056/NEJMoa011303.

9. Heerspink HJL, Stefánsson BV, Correa-Rotter R, Chertow GM, Greene T, Hou $\mathrm{FF}$, et al. DAPA-CKD trial committees and investigators. Dapagliflozin in patients with chronic kidney Disease. N Engl J Med. 2020;383(15):1436-46. https://doi.org/10.1056/NEJMoa2024816.

10. Perkovic V, Jardine MJ, Neal B, Bompoint S, Heerspink HJL, Charytan DM, et al. CREDENCE trial investigators. Canagliflozin and renal outcomes in type 
2 diabetes and nephropathy. N Engl J Med. 2019;380(24):2295-306. https:// doi.org/10.1056/NEJMoa1811744

11. Lage MJ, Boye KS, Bae JP, Wu J, Mody R, Botros FT. The association between the severity of chronic kidney disease and medical costs among patients with type 2 diabetes. J Med Econ. 2019;22(5):447-54. https://doi.org/10.1 080/13696998.2019.1581208.

12. Lim GJ, Liu YL, Low S, Ang K, Tavintharan S, Sum CF, et al. Medical costs associated with severity of chronic kidney Disease in type 2 diabetes mellitus in Singapore. Ann Acad Med Singap. 2020;49(10):731-41. https:// doi.org/10.47102/annals-acadmedsg.202032.

13. Low S, Lim SC, Zhang X, Wang J, Yeo SJD, Yeoh LY, et al. Medical costs associated with chronic kidney disease progression in an Asian population with type 2 diabetes mellitus. Nephrology. 2019;24:534-41.

14. Vupputuri S, Kimes TM, Calloway MO, Christian JB, Bruhn D, Martin AA, et al. The economic burden of progressive chronic kidney disease among patients with type 2 diabetes. J Diabetes Complicat. 2014;28(1):10-6. https:// doi.org/10.1016/j.jdiacomp.2013.09.014.

15. Ariyaratne TV, Ademi Z, Duffy SJ, Andrianopoulos N, Billah B, Brennan AL, et al. Cardiovascular readmissions and excess costs following percutaneous coronary intervention in patients with chronic kidney disease: data from a large multi-Centre Australian registry. Int J Cardiol. 2013;168(3):2783-90. https://doi.org/10.1016/j.jijcard.2013.03.128.

16. Wong CKH, Chen J, Fung SKS, Mok MMY, Cheng YL, Kong I, et al. Direct and indirect costs of end-stage renal disease patients in the first and second years after initiation of nocturnal home haemodialysis, hospital haemodialysis and peritoneal dialysis. Nephrol Dial Transplant. 2019;34(9): 1565-76. https://doi.org/10.1093/ndt/gfy395.

17. Meyer A, Bunzemeier H, Hausberg M, Walter M, Roeder N, Breithardt G, et al. Impact of different stages of chronic kidney disease on in-hospital costs in patients with coronary heart disease. Nephrol Dial Transplant. 2008; 23(6):1955-60. https://doi.org/10.1093/ndt/gfm879.

18. Doan KVD, Nguyen HTM, Nguyen NTH, Dang KC, Yang SH, Duong TV. Associations of socio-demographic, clinical and biochemical parameters with healthcare cost, health- and renal-related quality of life in hemodialysis patients: a clinical observational study. Int J Environ Res Public Health. 2020; 17:6552.

19. Darbà J, Marsà A. Chronic kidney disease in Spain: analysis of patient characteristics, incidence and direct medical costs (2011-2017). J Med Econ. 2020;27(12):1-7. https://doi.org/10.1080/13696998.2020.1830782.

20. Conde Olasagasti JL, Garcia Diaz JE, Carrasco Benitez P, Mareque Ruiz MÁ, Parras Partido MP, Moreno Alia I, et al. Cost analysis of integrated renal replacement therapy program in the province of Toledo (2012-2013). Nefrologia. 2017;37(3):285-92. https://doi.org/10.1016/j.nefro.2016.11.016.

21. Escobar C, Varela L, Palacios B, Capel M, Sicras A, Sicras A, et al. Costs and healthcare utilisation of patients with heart failure in Spain. BMC Health Serv Res. 2020;20(1):964. https://doi.org/10.1186/s12913-020-05828-9.

22. Sicras-Mainar A, Sicras-Navarro A, Palacios B, Varela L, Delgado JF. Epidemiología y tratamiento de la insuficiencia cardiaca en España: estudio PATHWAYS-HF. Rev Esp Cardiol. 2020. https://doi.org/10.1016/j.recesp.2020. 09.014.

23. Escobar C, Varela L, Palacios B, Capel M, Sicras A, Sicras A, et al. Epidemiology, clinical profile, management, and two-year risk complications among patients with chronic kidney disease in Spain. Nefrologia. (in press).

24. KDIGO. Chapter 1: Definition and classification of CKD. Kidney Int Suppl. 2013;3:19-62.

25. The Anatomical Therapeutic Chemical Classification System with Defined Daily Doses (ATC/DDD): World Health Organization. Available at: https:// www.who.int/classifications-/atcddd/en/. Last Accessed: 10 June 2020

26. General Council of Official Pharmacists' Colleges of Spain. Available at: https://botplusweb.portalfarma.com. Accessed 20 Apr 2021.

27. Statistics National Institute. 2017. Average labor profit according to age and gender. Accessed: 10 May 2020 Available at: https://www.ine.es/dynt3/ineba se/index.htm?padre $=4563 \&$ capsel $=4563$

28. Simal F, Martín Escudero JC, Bellido J, Arzua D, Mena FJ, González Melgosa I, et al. Prevalence of mild to moderate chronic kidney disease in the general population of Spain. Hortega study. Nefrologia. 2004;24:329-32.

29. Otero A, de Francisco A, Gayoso P, García F, EPIRCE Study Group. Prevalence of chronic renal disease in Spain: results of the EPIRCE study. Nefrologia. 2010;30(1):78-86. https://doi.org/10.3265/Nefrologia.pre2009.Dic.5732.

30. Gorostidi M, Sánchez-Martínez M, Ruilope LM, Graciani A, de la Cruz JJ, Santamaría R, et al. Chronic kidney disease in Spain: prevalence and impact of accumulation of cardiovascular risk factors. Nefrologia. 2018;38(6):606-15. https://doi.org/10.1016/j.nefro.2018.04.004.

31. Erraez S, López-Mesa M, Gómez-Fernández P. Mineralcorticoid receptor blockers in chronic kidney disease. Nefrologia (Engl Ed). 2021;41(3):258-75. https://doi.org/10.1016/j.nefro.2020.10.001.

32. Blacklock CL, Hirst JA, Taylor KS, Stevens RJ, Roberts NW, Farmer AJ. Evidence for a dose effect of renin-angiotensin system inhibition on progression of microalbuminuria in type 2 diabetes: a meta-analysis. Diabet Med. 2011;28(10):1182-7. https://doi.org/10.1111/j.1464-5491.2011. 03341.x.

33. Epstein M, Reaven NL, Funk SE, McGaughey KJ, Oestreicher N, Knispel J. Evaluation of the treatment gap between clinical guidelines and the utilization of renin-angiotensin-aldosterone system inhibitors. Am J Manag Care. 2015;21(11 Suppl):S212-20.

34. Mosenzon O, Wiviott SD, Cahn A, Rozenberg A, Yanuv I, Goodrich EL, et al. Effects of dapagliflozin on development and progression of kidney disease in patients with type 2 diabetes: an analysis from the DECLARE-TIMI 58 randomised trial. Lancet Diabetes Endocrinol. 2019;7(8):606-17. https:/doi. org/10.1016/S2213-8587(19)30180-9.

35. Bermejo S, García CO, Rodríguez E, Barrios C, Otero S, Mojal S, et al. The renin-angiotensin-aldosterone system blockade in patients with advanced diabetic kidney disease. Nefrologia. 2018;38(2):197-206. https://doi.org/10.1 016/.nefro.2017.07.003

36. Morales E, Gutiérrez E, Caro J, Sevillano A, Rojas-Rivera J, Praga M. Beneficial long-term effect of aldosterone antagonist added to a traditional blockade of the renin-angiotensin-aldosterone system among patients with obesity and proteinuria. Nefrologia. 2015;35(6):554-61. https://doi.org/10.1016/j. nefro.2015.09.008.

37. Gansevoort RT, Correa-Rotter R, Hemmelgarn BR, Jafar TH, Heerspink HJ, Mann JF, et al. Chronic kidney disease and cardiovascular risk: epidemiology, mechanisms, and prevention. Lancet. 2013;382(9889):339-52. https://doi.org/10.1016/S0140-6736(13)60595-4.

38. Coresh J, Turin TC, Matsushita K, Sang Y, Ballew SH, Appel L, et al. Decline in estimated glomerular filtration rate and subsequent risk of end-stage renal disease and mortality. JAMA. 2014;311(24):2518-31. https://doi.org/10.1 001/jama.2014.6634.

39. Ponikowski P, Voors AA, Anker SD, Bueno H, Cleland JG, Coats AJ, et al. Authors/Task Force Members; Document Reviewers. 2016 ESC Guidelines for the diagnosis and treatment of acute and chronic heart failure: The Task Force for the diagnosis and treatment of acute and chronic heart failure of the European Society of Cardiology (ESC). Developed with the special contribution of the Heart Failure Association (HFA) of the ESC. Eur J Heart Fail. 2016;18:891-975.

40. Nikolic M, Zivkovic V, Jovic JJ, Sretenovic J, Davidovic G, Simovic S, et al. SGLT2 inhibitors: a focus on cardiac benefits and potential mechanisms. Heart Fail Rev. 2021. https://doi.org/10.1007/s10741-021-10079-9 Epub ahead of print

41. McGuire DK, Shih WJ, Cosentino F, Charbonnel B, Cherney DZI, Dagogo-Jack S, et al. Association of SGLT2 inhibitors with cardiovascular and kidney outcomes in patients with type 2 diabetes: a meta-analysis. JAMA Cardiol. 2021;6(2):148-58. https://doi.org/10.1001/jamacardio.2020.4 511.

42. McMurray JJV, Solomon SD, Inzucchi SE, Køber L, Kosiborod MN, Martinez FA, et al. Dapagliflozin in patients with heart failure and reduced ejection fraction. N Engl J Med. 2019;381(21):1995-2008. https//doi.org/10.1056/NEJMoa1911303.

43. Packer M, Anker SD, Butler J, Filippatos G, Pocock SJ, Carson P, et al. Cardiovascular and renal outcomes with Empagliflozin in heart failure. N Engl J Med. 2020;383(15):1413-24. https://doi.org/10.1056/NEJMoa2022190.

44. Murton M, Goff-Leggett D, Bobrowska A, Garcia Sanchez JJ, James G, Wittbrodt E, et al. Burden of chronic kidney Disease by KDIGO categories of glomerular filtration rate and albuminuria: a systematic review. Adv Ther. 2020. https://doi.org/10.1007/s12325-020-01568-8 Epub ahead of print.

45. Roggeri A, Roggeri DP, Zocchetti C, Bersani M, Conte F, ReNe (Renal Lombardy Network); Additional contributors from ReNe Network. Healthcare costs of the progression of chronic kidney disease and different dialysis techniques estimated through administrative database analysis. J Nephrol. 2017;30(2):263-9. https://doi.org/10.1007/s40620-016-0291-8.

46. Jommi C, Armeni P, Battista M, di Procolo P, Conte G, Ronco C, et al. The cost of patients with chronic kidney failure before Dialysis: results from the IRIDE observational study. Pharmacoecon Open. 2018;2(4):459-67. https:// doi.org/10.1007/s41669-017-0062-z. 
47. Szucs TD, Sandoz MS, Keusch GW. The cost-effectiveness of losartan in type 2 diabetics with nephropathy in Switzerland--an analysis of the RENAAL study. Swiss Med Wkly. 2004;134:440-7.

48. de Portu S, Citarella A, Cammarota S, Menditto E, Mantovani LG. Pharmacoeconomic consequences of losartan therapy in patients undergoing diabetic end stage renal disease in EU and USA. Clin Exp Hypertens. 2011; 33(3):174-8. https://doi.org/10.3109/10641963.2010.531846.

49. Hopkins RB, Garg AX, Levin A, Molzahn A, Rigatto C, Singer J, et al. Costeffectiveness analysis of a randomized trial comparing care models for chronic kidney disease. Clin J Am Soc Nephrol. 2011;6(6):1248-57. https:// doi.org/10.2215/CJN.07180810.

50. Olufade T, Lamerato L, Sánchez JJG, Jiang L, Huang J, Nolan S, et al. Clinical outcomes and healthcare resource utilization in a real-world population reflecting the DAPA-CKD trial participants. Adv Ther. 2021;38(2):1352-63. https://doi.org/10.1007/s12325-020-01609-2. Epub ahead of print.

\section{Publisher's Note}

Springer Nature remains neutral with regard to jurisdictional claims in published maps and institutional affiliations.

Ready to submit your research? Choose BMC and benefit from:

- fast, convenient online submission

- thorough peer review by experienced researchers in your field

- rapid publication on acceptance

- support for research data, including large and complex data types

- gold Open Access which fosters wider collaboration and increased citations

- maximum visibility for your research: over $100 \mathrm{M}$ website views per year

At $\mathrm{BMC}$, research is always in progress.

Learn more biomedcentral.com/submissions 